\title{
Portret krytyka z czasów młodości. O kształtowaniu się tożsamości krytycznej Jana Błońskiego
}

Małgorzata Szumna 


\section{Portret krytyka z czasów młodości. O kształtowaniu się tożsamości krytycznej Jana Błońskiego*}

Małgorzata Szumna
Artykułzostał przygotowany w ramach prac nad projektem finansowanym ze środków Narodowego Centrum Nauki przyznanych na podstawie decyzji numer DEC-2012/05/N/ $\mathrm{HS} 2 / 01278$.

TEKSTY DRUGIE 2017, NR 5, S. 70-87

DOI: $10.18318 / \mathrm{td} .2017 \cdot 5 \cdot 5$

Dierwszą część pisanej przez lata książki o Witkacym Błoński zatytułuje prosto: Od Stasia do Witkacego ${ }^{1}$. I cel postawi przed sobą na pierwszy rzut oka niezwykle przejrzysty: prześledzić początki tej drogi twórczej, uchwycić ruch formowania się osobowości, odnaleźć osoby i zjawiska mające wpływ na jednostkę, kształtujące ją, w jakimś sensie nadające jej tożsamość. Nie tak łatwe jest jednak odtworzenie tego samego gestu w odniesieniu do krytyka, który tak widział swoje zadania. Nie z braku materiału może żaden okres życia Błońskiego nie jest tak dobrze udokumentowany jak lata szkolne; zachowały się pieczołowicie przechowywane zeszyty do języka polskiego, bruliony z wypracowaniami, zapiski osobiste, wreszcie duża teka ze wczesnymi próbami literackimi (wierszami

* Pierwszą wersję artykułu przedstawiłam podczas zebrania Katedry Krytyki Współczesnej WP UJ. Uczestnikom tego spotkania bardzo dziękuję za dyskusję i za uwagi, które pozwoliły na dalsze uzupełnienia tekstu.

1 J. Błoński Od Stasia do Witkacego, Wydawnictwo Literackie, Kraków 1997.
Małgorzata Szumna

- dr, związana

z Ośrodkiem Badań

nad Awangardą

WP UJ. Zajmuje się

historią literatury polskiej drugiej połowy

XX wieku, historią

krytyki literackiej oraz historią intelektualną, szukając na przecięciu tych dyscyplin języka pozwalającego na opisanie przygód inteligencji polskiej tamtego czasu. Obecnie pracuje nad biografią intelektualną Jana Błońskiego. Kontakt: malgorzata. szumna@gmail.com 
i przekładami) - na odwrocie ostatniej karty, która się w niej znajduje, ktoś (sam autor zapewne) po latach dopisał, mocno przyciskając stalówkę: „Zostawić" . Dokumenty te dziwnie nie pasują do archiwum, zdają się burzyć założony w nim ład, wymykają się temu sztucznie skonstruowanemu porządkowi, jakim jest każda struktura archiwalna. Oznaczają, że dostajemy do ręki świadectwa, które w większości nie powinny były przetrwać; zostajemy postawieni w roli podglądacza, któremu dano dostęp do - niedojrzałości; niedojrzałości, która dopiero stopniowo przełamuje się w dojrzałość. Kłopot z odtworzeniem rzeczywistych początków Błońskiego polega na tym głównie, że bardzo trudno uchwycić moment, w którym notowane pod szkolnymi rozprawkami uwagi polonistki - „Przegląd zadań wykazuje, że opanowałeś całość materiału i orientujesz się w istotnych cechach i wartościach prądów literackich. Szkoda tylko, że nie potrafisz nagiąć się do pracy wytrwałej i systematycznej”3 - stają się niestosowne. To komentarz z marca 1947 roku - Jan Błoński ma wówczas lat 16 i jest w takim samym stopniu Jasiem, jak i Błońskim właśnie.

\section{2.}

Podsumowując po latach okres toruński, Błoński dość zdawkowo komentował będzie rolę nauczycieli i autorytetów - tak jakby zacząć się miał dopiero w Krakowie. A przecież coś jednak im zawdzięczał. Zeszyty do języka polskiego świadczą dobitnie o tym, że jego polonistka miała ambicje wykraczające nieco poza samą realizację programu szkolnego: chciała uczniów wyczulić na zjawiska bieżącego życia literackiego, oczekiwała od nich, że wdrożą się do jego śledzenia - stąd np. odniesienia do powieści Hanny Malewskiej Kamienie wołać będa, które uzupełniały wykład poświęcony literaturze dawnej, bądź też próba nakłonienia słuchaczy do prześledzenia dyskusji toczącej się wówczas na łamach „Twórczości”, a dotyczącej oceny literackiego dorobku dwudziestolecia. Nieubłaganie tępiła ona również stylistyczną dezynwolturę ucznia: wypracowania Błońskiego są zapisem pojedynku znudzonego gimnazjalisty, którego wyraźnie drażni miałkość narzucanej mu tematyki, i nauczycielki,

2 Archiwum Jana Błońskiego (Biblioteka Jagiellońska w Krakowie, dalej skrót AJB), Przyb. 100/13 Zeszyty szkolne Jana Błońskiego z wypracowaniami z języka polskiego z lat 1945-1947; Przyb. 342/10 Wiersze, przekłady z poetów francuskich oraz pastisze. Bruliony młodzieńczych utworów; Przyb. 96/13 Pamiętnik (1946-1948); Przyb. 97/13 Fragmenty dziennika oraz zapiski osobiste (1950).

3 AJB, Przyb. 100/13. 
która tę szkolną rutynę musi swoim wysiłkiem legitymizować. Jej żądanie precyzji i stanowcze podważanie poglądów niewystarczająco jasno wyrażonych bądź też nieuargumentowanych przyniosło jednak w końcu oczekiwany skutek - nawet jeśli praca ta wykonywana była na materiale tak marnym, jak pisanie przemówień na zebrania postępowej organizacji młodzieżowej, której patronować miała myśl Asnyka.

Jak się jednak wydaje, w gronie pedagogicznym Gimnazjum i Liceum Akademickiego im. Mikołaja Kopernika, które kończył Błoński, zabrakło rzeczywistych indywidualności: lekcje języka polskiego uwrażliwiały na tech$n e$, uczyły podstaw rzemiosła, nie były jednak w ostatecznym rozrachunku rzeczywistym wyzwaniem intelektualnym. $\mathrm{O}$ wiele ważniejsze pozostawało więc samokształcenie, żarliwość czytania i dyskutowania o tym, co przeczytane. By jednak sam ten akt lektury był możliwy, do książek trzeba było dopiero dotrzeć. W opublikowanym w 1975 roku wspomnieniu Błoński opowie o człowieku, który w dużej mierze dał mu szansę wejścia w świat literatury a więc o Zygmuncie Czernym. Pisze on tam:

Nigdy później tyle nie przeczytałem, co między 1947 a 1950 rokiem; i nigdy z takim drżeniem i niecierpliwością. Czerny dał mi - w stosunku do rówieśników - ogromne wyprzedzenie; nieświadomie przygotował do polskiej literatury lat sześćdziesiątych. Już Becketta i Robbe-Grilleta, aby pozostać przy francuskich przykładach, czytałem bez zdumienia, n a t u r a l n i e... Można od biedy uczyć się samemu, ale z książkami; bez książek - albo ze śmieciem do dyspozycji - i najlepszy pedagog nie pomoże. Musi zostać zachowane poczucie hierarchii... i poczucie ciągłości. [...] Przecie prawie wszystko, co wtedy czytałem, było oficjalnie uznane za makulaturę... Ale on ani się tym przerażał ani głośno oburzał. Pozwalał mówić tekstom. Takie miał spokojne zaufanie do literatury. Odległy już od aktualności literackiej, oddał mi największą, jaką mógł, przysługę. I najbardziej aktualnie potrzebną. ${ }^{4}$

W jednym z kalendarzy prowadzonych wówczas przez Błońskiego odnaleźć można kilka różnych spisów lektur: pierwszy z nich sprawia wrażenie listy sobie samemu zadawanej i zawiera wyłącznie francuskie tytuły, będąc jednocześnie

4 J. Błoński Wspomnienie [Kim byłbym bez nich...] " "Tygodnik Powszechny” 1975 nr 23, s. 1-2 (cytuję za maszynopisem, s. 5 - AJB Przyb. 18/11 Artykuły poświęcone Kazimierzowi Wyce, przy tym materiały warsztatowe do tematu). 
przede wszystkim przeglądem międzywojennej francuskiej prozy; drugi - jak się zdaje - jest po prostu wykazem przeczytanych w ciągu ostatnich miesięcy książek: tu już o wiele bardziej widoczna jest równowaga i zróżnicowanie zarazem; lektur polskich jest mniej więcej tyle samo co francuskich; poezja nieznacznie dominuje nad prozą. Spora część tych francuskojęzycznych lektur pochodziła z prywatnej biblioteki Czernego, trudno dziś jednak powiedzieć, na ile starał się on ukierunkowywać wybory młodego podopiecznego, na ile zaś uświadamiał sobie, że największe pożytki przynieść tu może po prostu swoboda wyboru. „Czerny najpierw się opierał, krzywił, pierwsze książki pożyczał z uprzejmości dla rodziców. Ale kiedy poprosiłem o Mallarmégo i Apollinaire’a, zmienił się nagle. [...] Trudno to sobie teraz wyobrazić, mały Toruń, bieda, niepewność przyszłości, liceum, na widnokręgu - Nr 16 produkuje. I te książki5". Księgozbiór Czernego był eklektyczny - jak bowiem wspominał Błoński: jego właściciel gromadził książki namiętnie, kierując się przy tym raczej potrzebą budowania kolekcji dającej możliwie szeroki ogląd niż chęcią uzyskania zbioru mającego jedną wyraźną dominantę. Niemniej jednak zainteresowania młodego czytelnika - choć wciąż zróżnicowane - miały bardziej jednoznaczny kierunek: Błoński wydobywał spośród tych tytułów przede wszystkim rzeczy najnowsze, wyraźnie eksperymentalne, nowatorskie: czytał Bretona, Éluarda iTzarę, sięgał po Valéry'ego i Prousta. Te jego sympatie widać nawet w spisywanym po latach komentarzu: z uznaniem wspomina on o intelektualnej otwartości profesora, który gromadził także pozycje z pozoru odległe zarówno od jego zainteresowań naukowych, jak i czytelniczych preferencji, był natomiast zawsze na bieżąco z tym, co aktualnie we Francji wydawano - tym samym zaś awangardę odkrył niejako wcześniej, niż to było możliwe w Polsce; śledził ją, gdy ta dopiero na polskim gruncie raczkowała (mowa oczywiście o awangardzie konstruktywistycznej). Zwracam uwagę na te literackie wybory młodego Błońskiego zwłaszcza na nadrealistów - ponieważ komplikują one i uwieloznaczniają stanowisko, które on sam często prezentował, mówiąc, że do Krakowa przyjechał dla Wyki. Dla Wyki - owszem, ale dla Wyki-charyzmatycznego krytyka, aktywnie kształtującego rzeczywistość literacką, nie zaś dla Wyki - jeśli wolno to tak określić - prawodawcy, ich wybory literackie były wszakże na początku znacząco odmienne; spokrewniały one Błońskiego nie tyle z autorem Pogranicza powieści, co z Sandauerem, Ważykiem czy Bieńkowskim. Są to przy tym wybory bardzo istotne: będą bowiem dla Błońskiego stanowić ważki punkt odniesienia w latach socrealizmu.

5 Tamże. 
3.

Ta logika rozwoju Błońskiego - kierująca go w stronę tego, co Artur Sandauer zwykł był nazywać „sztuką nowatorską" - jest przy tym łatwiejsza do uchwycenia na przykładzie jego wczesnych prób literackich niż krytycznych. $\mathrm{Z}$ dwóch powodów: po pierwsze - nie zachowały się w większości najwcześniejsze teksty będące próbą krytycznoliterackiej konceptualizacji literatury eksperymentalnej; z listów do Błońskiego wiadomo np., że próbował on jeszcze w 1946 roku opisać Przybosia; tekst ten - jak się wydaje - nie zachował się jednak, w szczątkowej postaci został prawdopodobnie włączony do opublikowanej dopiero w 1949 roku recenzji z dwóch pierwszych tomów poetyckich Różewicza ${ }^{6}$; po drugie - wiersze Błońskiego w dużej mierze przeczyły urojeniom literackich nowatorów, przez co rozumiem to, że bardzo mocno zakorzenione były w tradycyjnej praktyce emulacji; droga do oryginalności swój początek miała w naśladownictwie. Stąd też znaczenie przekładów: były one nie tylko treningiem giętkości języka, służyły przede wszystkim uczeniu się coraz to nowych dykcji - Błoński spolszczał wówczas (pod koniec szkolnej edukacji) m.in. Supervielle’a i Valéry’ego. Jego własne próby poetyckie przypominają momentami centony - kluczem do nich okazuje się bowiem swobodna wędrówka metafor, przenoszonych - nie do końca chyba świadomie - z twórczości autorów szczególnie mu bliskich; rezultat przypomina często wysiłek autora pastiszu, który do tego stopnia wchodzi w styl cudzy, że gubi własny. Tę płynność i swoistą bezstylowość (przy eksperymentalnym sztafażu) najlepiej uchwycił człowiek wówczas Błońskiemu najbliższy - Konstanty Puzyna. W jednym z listów z początku 1947 roku komentował on:

Twoje wiersze. Oczywiście najlepszy Poemat nieprawdopodobny, szczególnie początek, gdzie prowadzisz wątek „myśli i wspomnień” obok rozwijania pejzażu nadmorskiego. Wiersz pod Jastruna nieźle podchwycony stylem, ale zupełnie odbiegający myślą (coś zresztą zaznaczył z boku). Skąd nagle wjeżdżasz z "gwiazdą granatu"? W ogóle wszystkie nie są złe, choć może zbyt mało mają jędrności i zwartości. W Poemacie np. zbyt wiele marnujesz słów dla stworzenia poszczególnych obrazów. To zresztą z czasem nabędziesz. Gorzej, że wszystkie te wiersze są "dęte”. I tu widzę dla Ciebie niebezpieczeństwo. Nie ma w tym wierszach szczerości. Podejrzewam, że tworzysz je, jak rebus: wpadniesz na pomysł i układasz słowa, na zimno,

6 J. Błoński Poezja Różewicza, "Twórczość” 1949 nr 7, s. 111-117. 
bez uczucia. Twórz lepiej pod wpływem właśnie uczucia, impulsu; formę możesz wycyzelować później, albo w ogóle nie poświęcać jej większej uwagi. Z czasem ona sama Ci się wytworzy z własnym stylem. Dziś zapomnij raczej o niej, nie cyzeluj, nie „stylizuj”, nie baw się w efektowne układanie słów, bo zamiast „bani z poezją” stworzysz... nocnik, może nawet z saskiej porcelany, ale pusty, a jeśli napełniony, to, jak każdy nocnik, rzeczą ani przyjemną, ani wartościową. ${ }^{7}$

7 Listy Konstantego Puzyny do Jana Błońskiego 1947-1950, wstęp i opr. M. Szumna, "Dialog” 2017 $\mathrm{nr} 4$, s. 78. Poemat nieprawdopodobny (jak i inne próby poetyckie Błońskiego, w tym naśladowanie z Jastruna) zachował się w archiwum, w dwóch wersjach - rękopisie i różniącym się od niego maszynopisie. Cytuję za tym drugim:

Poemat nieprawdopodobny

Senne paprocie wielkich nadmorskich lasów, uczepione wszystkimi korzeniami zeszłowieczornych wspomnień

Uliczki wiosek rybackich, przekreślone cieniami podartych sieci i linią wozu, spieszącego do swych zapomnianych myśli,

Moje dnie, przeciekające między palcami jak meduzy, wielkie, oślizgłe meduzy o karminowych pręgach widzenia....

Rzuciłem meduzę w żółtą pianę wschodzącego księżyca, nerwowego i płynnego w płomieniu gorącego dnia, o powietrzu drżącym i nabrzmiałym wonią pocałunków,

Złego i zakłopotanego w świetle własnego odbicia, wiecznie skłóconego ze swym zeszłotygodniowym bratem-nowiem,

Obojętny dla spraw ludzi i meduz, nie dojrzał wypolerowanego snem krążka o brzegach z przelewających się metali zapomnienia,

Niebaczny, urósł do rozmiaru wszechświata i poczuł się ogromną, szklaną kulą u pułapu stołecznego teatru.

Aktorzy, zamieniwszy swe cienie z cieniami zwielokrotnionej, znudzonej już meduzy uciekali zmartwieni w ciemne korytarze i wilgotne piwnice teatralnych zwierzeń,

Spadali po drodze z bursztynowych ławek, chropawych jak kora uschłego dębu,

Gubiąc po drodze maski o oczach z ołowiu, wtopionego w zdumienie i sen, połykali gorączkowe słoiki różu, pozostawionego przez zmęczone amantki,

Żebrząc o los, uwolniony od krzyku meduzy, wpadali w wielkie kadzie pełne barwnego złota i jesiennych liści.

Księżyc, ożeniony z amebą,

Wielkie, zapomniane paprocie nadmorskich wzgórz,

Sieci, ciężkie od zwierzeń topielców i pieszczot pulsujących alg,

Przezroczyste i nieobecne oczy, pełne zielonych kropel ściekających z podartych wierszy Baudelaire'a

Moje dnie, przeciekające pomiędzy palcami, jak pochyłe, zgęszczone meduzy. 
Rzecz ciekawa: Puzyna - podzielający przecież literackie preferencje Błońskiego, a może nawet bardziej od niego przywiązany wówczas do awangardy w ścisłym znaczeniu tego słowa - wytykał mu de facto mechaniczne powielanie awangardowych inspiracji, uczulał go na to, co w krytycznoliterackim języku epoki można by określić mianem „formalizmu”. A może nawet mocniej: formalizm ten po części mu wytykał; widział w tych zaczątkach literackiej twórczości nie tyle nadmiar intelektualizmu, co przesadne poddawanie się urokom poetyckiego konceptu; poezja jako taka stawała się więc luźną grą środków retorycznych, oderwanych jednak od rzeczywistego przeżycia piszącego. Przypominam te zastrzeżenia nie tylko dlatego, że wydają mi się dość trafną oceną tych tekstów. Mając je w pamięci, można bowiem lepiej zrozumieć wczesne krytycznoliterackie wypowiedzi Błońskiego: będą one wszakże próbowały opisać poezję, która zarazem oddaje prawdę rzeczywistości i odważnie podejmuje wyzwania nowoczesnej poetyki; stąd też zapewne pierwsze poetyckie wybory Błońskiego to Miłosz - i Różewicz.

\section{4.}

Tekst, który można by uznać za krytycznoliteracki debiut Błońskiego, właściwie debiutem nie jest - nigdy się przecież nie ukazał ${ }^{8}$. Ale napisana na początku 1947 roku odpowiedź na ankietę „Odrodzenia” dotyczącą wyboru najważniejszej książki dwulecia spełnia już wszelkie warunki wypowiedzi na tyle dojrzałej, by wolno było uznać, że decyzja o jej nieopublikowaniu miała charakter w dużej mierze przypadkowy. Czuł to Puzyna - ledwie o dwa lata od Błońskiego starszy, ale dobrze już osadzony w literackim środowisku, współpracujący regularnie z „Odrodzeniem” i „Nowinami Literackimi”; w korespondencji objawiający się więc na zmianę w roli życzliwego partnera

8 AJB Przyb. 353/10 Artykuły i rozprawy poświęcone zagadnieniom literackim, w tym m.in. ankieta "Odrodzenia” oraz cykl "Teksty drobne”. (Wszystkie dalsze cytaty z tego tekstu pochodzą z tego archiwum). Omawiany artykuł był przygotowaną przez Błońskiego odpowiedzią na ankietę ogłoszoną przez redakcję "Odrodzenia”, w której pytano o najbardziej istotną książkę dwulecia. Sam Błoński wypowiadał się o nim po latach dość cierpko: „Bardzo wcześnie, jeszcze w liceum, przeżyłem absolutne oczadzenie Ocaleniem. Czytałem wtedy «Odrodzenie», które ojciec prenumerował, znalazłem tam ankietę /aka jest najwybitniejsza ksiq̨żka roku 1947 i napisałem długą, kilkunastostronicową odpowiedź. Zachowałem nawet kopię tego - zdecydowanie nudnego - elaboratu. Najzabawniejsze, że właśnie ja, licealista z Torunia, miałem rację, bo Ocalenie jest istotnie najlepszą książką wtedy wydaną [...]" (Najlepsze lata. Z Janem Błońskim rozmawiają Krystyna i Stefan Chwinowie, w: Błoński przekorny. Dzienniki. Wywiady, wyb. i oprac. M. Zaczyński, Znak, Kraków 2011, s. 429). 
i surowego mentora. Rozwiewając wątpliwości potencjalnego debiutanta, komentował na marginesie przesłanego mu zawczasu maszynopisu:

Twoja odpowiedź na ankietę „Odrodzenia” - jest zupełnie możliwa. Masz duże zdolności krytyczne (mówię serio), szczególnie dobrze precyzujesz niektóre, dość zawiłe, sprawy. W porównaniu z wypracowaniami szkolnymi w kl. IV, które były szczytem zawiłości i chaosu myślowego, zrobiłeś ogromny postęp. Oczywiście cała „odpowiedź” jest, jak piszesz, szkolarska, ale mogłaby być o wiele mniej szkolna, gdybyś nie wspominał ciągle o sobie i swoich 16-tu latach. W krytycznym opracowaniu jakiegoś dzieła osoba krytyka powinna być jak najmniej widoczna; chyba, jeśli stawiasz szczególnie ryzykowną czy oryginalną tezę, możesz ewentualnie zastawić się słowami: „moim zdaniem... " czy czymś w tym rodzaju. Poza tym staraj się używać mniej nawiasów i cudzysłowów; odbiera to prozie płynność i potoczystość i zabija lekkość stylu. W ogóle jednak pracuj w tym kierunku; może coś z Ciebie będzie. - Z Pregerówną9 rzeczywiście sporo rzeczy w Twej odpowiedzi się pokrywa. No, trudno. Zresztą nie potrzebowałeś być szczególnie oryginalny, bo nie była to przecież wła s n a praca krytyczna, tylko odpowiedź na ankietę, miałeś więc prawo powtarzać nawet cudze sądy. ${ }^{10}$

Wyeksponowanie „szesnastoletniej mądrości” przez piszącego faktycznie wywoływało niezamierzony efekt komiczny, ale przecież poza tym był to tekst zupełnie już dopracowany. Błoński za najważniejszą książkę dwulecia uważał Ocalenie Miłosza - wybór o tyle mało zaskakujący, że nietrudno zauważyć, iż odnajdywał w jego twórczości to wszystko, czego brak wytykał mu Puzyna: a więc przede wszystkim harmonijne połączenie uczuć i intelektu, jak to określał sam Błoński: „doskonały stop silnej emocjonalności z wizją plastyczną”. W uzasadnieniu wyboru nie koncentrował się on jednak na aspektach - by znowu użyć jego określenia - formalnych, lecz stawiał tezę, że „realizm w poezji” możliwy jest w jednej tylko postaci: „reagowania na «stawanie się» historii". Miłosz w tej wykładni okazywał się "poetą naszego czasu" ze względu na niezwykłe wyczulenie na coś, co można by nazwać - choć nie jest to termin samego Błońskiego - pierwiastkiem temporalnym. Krytyk uważnie śledził jego ewolucję: postawę poety z wczesnych lat 30. nazywał „zagubieniem

9 J. Pregerówna Poezja po wojnie, "Odrodzenie" 1947 nr 7 (116), s. 8. 
w historii" i podkreślał przy tym, że Miłosz reagował jak sejsmograf: jego ogląd rzeczywistości oddawał to, co wolno by nazwać duchem epoki. Miłoszowy katastrofizm miał jednak - w tej interpretacji - podlegać znamiennej ewolucji: nie był - używając określeń komentatora - katastrofizmem klerka, który ucieka w estetyzm (tak Błoński postrzegał Czechowicza), lecz postawą człowieka, który rozumie, że tylko katastrofa może przynieść oczyszczenie, a co za tym idzie - także przyszłe odrodzenie. Błoński przeciwstawiał sobie dwa Miłoszowe cykle - Świat i Głosy biednych ludzi - by w ten sposób uwypuklić dwutorowość myślenia poety. Posłuchajmy:

„Świat" - to podróż na szczęśliwe wyspy, to odkrycie „prawdy ziemi”. To rzeczywiście świat przez wielkie ś, taki, jaki jest w swej najgłębszej istocie, świat-ideał, przyćmiony przez ludzką złość, do którego my „zagubieni w lesie" mamy dążyć. Opiera się według mnie na czterech filarach: obiektywne widzenie świata („naiwne” - „świat istnieje naprawdę”), zasadniczy optymizm [...], pochwała indywidualizmu i prawo do piękna.

Zaraz potem dodawał: „Wydaje mi się, że Gtosy nie są niczym innym, jak zetknięciem się Świata ze światem (codziennym)". Są więc formą uzupełnienia - albo korekty. Błoński zdaje się opisywać te dwa cykle w kategoriach nierozerwalnego związku, logiki wynikania - Ocalenie czytane jako całość jest więc zapisem przezwyciężania - krytyk, komentując Pieśni Adriana Zielińskiego, mówi o nich jako „pamflecie na Świat, który pozostał wyłączną własnością jego odkrywcy - poety". I zaraz zwraca uwagę na wynikające stąd uspołecznienie: zadaniem poety okazuje się bowiem w ostatecznym rozrachunku „doprowadzanie świata do Świata”, w tym kryje się ocalenie.

\section{5.}

Tyleż ta myśl zdaje się przy tym wynikać z Miłosza, co z narzucenia mu pewnych kategorii przez czytającego, który - chcąc wyeksponować jego współczesność - musiał spróbować o nim opowiedzieć, używając pojęć aktualnych; bez wątpienia chęć nawiązania do toczonych wówczas dyskusji znajdowała swoje odbicie w sięgnięciu po kategorię „realizmu w poezji”, być może przynajmniej po części - miała ona przełożenie na tak mocne uwypuklenie pokonywania indywidualistycznych ograniczeń tej twórczości. W roku 1947 Błoński wciąż jeszcze mógł sobie pozwolić na daleko idącą interpretacyjną i stylistyczną swobodę, nie będzie więc - jak sądzę - nadużyciem 
rozpatrywanie zastosowanych przez niego podejść i metod jako jego w pełni własnych wyborów, nie zaś przejawów dopasowywania się do narzuconych z góry wymogów. Już w tej pierwszej krytycznoliterackiej próbie widzimy Błońskiego-personalistę: chce on wejść w myśl poety, nie po to przecież by z nią polemizować, lecz by jej - towarzyszyć. „Patrzyłem nań - mówi wprost w tym tekście krytyk - jak czytelnik, który stara się uchwycić myśl autora"; deklaracja ta nie ma przy tym być świadomą wypowiedzią metodologiczną, a tylko świadectwem skromności: odsyła ona do aktu uczciwej lektury, który powinien być podstawą do udzielenia sobie samemu prawa głosu; uczciwość lektury wiąże się zaś ściśle z chęcią zrozumienia argumentów twórcy (nawet jeśli nie zgadzają się one z naszym własnym stanowiskiem). A uspołecznienie? Dotyka ono przecież samego nerwu krytyki Błońskiego, dla którego zawsze tak ważki będzie problem społecznego oddziaływania literatury, tego, w jaki sposób wchodzi ona w dialog z potrzebami czytelnika, ale też je formuje bądź zwrotnie przekształca. Błoński w swoim opisie Miłosza bardzo mocno zaakcentował dynamikę, zdolność do przeistaczania się, nieustannego szukania nowego siebie - ta dynamika jest jednak ściśle powiązana z czujnością na impulsy zewnętrzne, nie jest orgią solipsyzmu. Takie widzenie - raczej przeczuwane niż otwarcie formułowane - literatury przekładało się także na prześwitujące przez uwagi Błońskiego rozumienie krytyki: ona również nie miała być formą samoekspresji piszącego, lecz raczej wysiłkiem mapowania rzeczywistości - stąd też próbę usytuowania Ocalenia na tle innych książek tego okresu uznać należy nie tylko za erudycyjny ozdobnik; jest w tym już zarys przyszłej potrzeby syntezowania.

Oczywiście, tekst ten został napisany przez szesnastolatka - który mówił tam sam o sobie: „mam zaledwie szesnaście latek i dlatego pewnie [uzasadnienie wyboru - M.Sz.] będzie miało charakter szkolarski i [...] nudny" - najciekawsze jest w nim więc uchwycenie przełamywania się poetyk. Błoński nie tyle jest tam już bowiem „poważnym krytykiem”, co dopiero stroi się w takie piórka - w efekcie zaś nie zawsze jeszcze kontroluje nagłe wybuchy emocji, z przesadną łatwością posługuje się emfazą, często uzasadnia sądy w sposób pozaracjonalny, odwołując się przede wszystkim do własnego doświadczenia lektury. Jak doskonale wiemy, z czasem elementy te - poddane wyraźnemu rygorowi przez piszącego - staną się jednym z najbardziej rozpoznawalnych składników jego stylu. Tu jawią się nam one jeszcze w całym swoim rozpasaniu, wymykają się spod kontroli, odsłaniają mimowolnie wiek autora - a bardziej od wieku jeszcze jego brak doświadczenia, pozwalając na podglądanie procesu stawania się krytykiem. 
6.

Do właściwego debiutu Błońskiego doszło na łamach „Twórczości”: w lipcowym numerze z 1949 roku ukazał się jeden z ważniejszych tekstów bardzo młodego krytyka, wspomniana już obszerna recenzja z dwóch pierwszych tomów poetyckich Różewicza"1. Moment - wystarczy spojrzeć na datę - nie był najszczęśliwszy; debiut Błońskiego przypada na fatalny czas, naznaczony jest bowiem presją wywieraną na literaturę po zjeździe szczecińskim. Pamiętać jednak trzeba, że w krytyce ta inwazja socrealizmu dokona się z pewnym poślizgiem, unieruchomi ją i ujednoznaczni tak naprawdę dopiero w 1950 roku ${ }^{12}$. Szkic o Różewiczu niewątpliwie w dużej mierze powstał wcześniej; gdy zaczynamy go rozkładać na elementy pierwsze, szybko dochodzimy do wniosku, że przynajmniej w części został on ukształtowany zaraz po ukazaniu się Niepokoju, a więc jeszcze w 1947 roku. Janusz Degler ten lipcowy numer „Twórczości” nazwał kiedyś - choć w trybie hipotetycznym - „ostatnim głosem w obronie awangardy"13; poza dwugłosem w sprawie Różewicza (złożonym z tekstów Włodzimierza Maciąga i Błońskiego) zamieszczony został w nim przecież także artykuł Puzyny, będący recenzją ze świeżo wydanego wznowienia dramatów Witkacego. Autor tekstu o Różewiczu jest przy tym o dwa lata starszy od autora tekstu o Miłoszu - i już zupełnie inny. Odrobił on niewątpliwie lekcję Puzyny, odnieść można nawet wrażenie, że z pewną przesadą: jeśli w odpowiedzi na ankietę „Odrodzenia” tożsamość piszącego

11 J. Błoński Poezja Różewicza. Nie był to zresztą i w tym wypadku debiut sensu stricto - Błoński opublikował przed nim (również w 1949 roku) kilka drobnych recenzji, o zdecydowanie mniejszym ciężarze gatunkowym niż szkic krytyczny poświęcony Różewiczowi.

Por. uwagi dotyczące dynamiki i rozwoju krytyki socrealistycznej - m.in. J. Sławiński Krytyka nowego typu, w: tegoż Teksty i teksty, Wydawnictwo PEN, Warszawa 1991; D. Tubielewicz-Mattsson, Polska socrealistyczna krytyka literacka jako narzędzie władzy, distr. Uppsala University Library, Uppsala 1997; J. Smulski O polskiej socrealistycznej krytyce (i samokrytyce) literackiej, "Teksty Drugie" 2000 nr 1/2; M. Zawodniak Literatura w stanie oskarżenia. Rola krytyki w życiu literackim socrealizmu, Upowszechnianie Nauki-Oświata "UN-O”, Warszawa 1998; M. Pietrzak Socrealistyczna krytyka w ujęciu diachronicznym, Acta Universitatis Lodziensis, Folia Litteraria Polonica 10, 2008. Większość tych badaczy zgadza się do charakteru krytyki socrealistycznej i uznaje, że za okres jej panowania uznać można lata 1949-1956, najciekawsze w tym kontekście wydają się polemiczne rozpoznania Pietrzaka, który pytał o to, czy można mówić o krytyce socrealistycznej w porządku diachronicznym, wskazując tym samym na jej wcześniejsze i późniejsze przejawy i trwanie. Wydaje się, że można ją potraktować w kategoriach negatywnej matrycy także dla krytyki dużo późniejszej.

13 J. Degler Puzyna i „kłębowisko zwane Witkacym”, w: K. Puzyna Witkacy, opr. J. Degler, Warszawa 1999, korzystam z wersji online: http://www.witkacologia.eu/witkacolodzy/Puzyna.html (10.02.2017). 
była aż zanadto wyeksponowana, to w recenzji z Niepokoju i Czerwonej rękawiczki preferencji interpretatora trzeba się właściwie domyślać; ukryte są one przede wszystkim w samej strukturze wartościowania, konstruowania literackiej genealogii, zwłaszcza zaś - budowania perspektyw na przyszłość. Wiemy skądinąd, że czytanie Różewicza - wtedy, pod koniec lat 40. - było dla Błońskiego doświadczeniem szczególnie osobistym, nawiązywało bowiem do wczesnego zapisu z jego dziennika, jeszcze z roku 1946, gdzie wyznawał on otwarcie:

Jestem dzieckiem wojny. Powiedzenie to, choć bardzo szumne, zawiera w sobie wiele prawdy. Bo, chociaż podczas wojny się nie urodziłem, to jednak przyniosła mi ona - głównie w ostatnich swoich 2 latach zupełnie odmienny świat i b. wpłynęła na moją psychikę. Nie przeczę, że pewne podstawy - być może zasadnicze, jak sposób mojego wychowania - wziąłem sprzed wojny, jednak swoiste jej warunki uniemożliwiły mi wyjście z zaklętego koła kompleksu „drewnianego konia”. Tak bowiem muszę się niestety określić. Bohaterem bowiem tej właśnie powieści Brandysa - której początek poznałem w „Twórczości” jestem ja. ${ }^{14}$

To jedno z bardzo w sumie nielicznych świadectw powrotu Błońskiego do okresu wojennego. Różewicz ten świat przeżyć skonceptualizował. Nie oznacza to, oczywiście, że Różewiczowskie imaginarium pokrywało się ze światem wyobrażeń Błońskiego; co innego też jest tu istotne: spokrewniało ich ze sobą samo zarażenie wojną - u Różewicza, rzecz jasna, dużo bardziej rzeczywiste, u Błońskiego - na pewno mniej poddające się wtedy intelektualnemu przepracowaniu. Miało to określone konsekwencje dla sposobu, w jaki chciał on tę poezję opisywać: przede wszystkim dążył bowiem do włączenia jej i powiązania z najbliższą mu problematyką. Stąd zapewne budowanie siatki odniesień dla Różewiczowskiej liryki: Błoński wyprowadzał ją z wczesnego Miłosza, z odrzucanego z czasem - Przybosia, wreszcie - z francuskiego nadrealizmu (sięgnięcie doń miało bowiem - zgodnie z tezą komentatora - być sposobem na wyjście z symbolizmu, przy zanegowaniu drogi polskiej awangardy). Koncentrował się przy tym bardzo stanowczo na poetyckiej technice, na tym, co najbardziej sprawdzalne, co pozostaje zawsze konkretnym punktem odniesienia. Metoda ta musi zwrócić naszą uwagę - nie jest ona wszakże

14 AJB Przyb. 96/13. 
szczególnie charakterystyczna dla Błońskiego; poetologiczna analiza stanowi u niego o tyleż częściej zaledwie punkt wyjścia do rozbudowanej interpretacji. W tej recenzji Błoński maskuje zaś wszystko, czego nie mógłby wprost udowodnić, na co nie miałby przykładu. Czy to przejaw dojrzewania krytyka? Jeśli już, to co najwyżej jakiś etap przejściowy - wiadomo, że nie tak będzie w przyszłości wyglądać poetyka wypowiedzi krytycznych Błońskiego. Więc może: raz jeszcze ten mimetyzm, o którym wspomniałam wcześniej, powołując się na przykład poetyckich wystąpień Błońskiego; mimetyzm, który kazałby mu poszukiwać krytycznoliterackiego ekwiwalentu poezji Różewicza? Ta myśl wydaje się bardziej kusząca: poezja Różewicza - pokazuje Błoński opiera się na wysiłku minimalizacji, ogałacania, upraszczania języka. Może trud krytyka powinien iść w podobnym kierunku: anihilacji ozdobników, zostawienia tego tylko, co niezbędne? W takiej wykładni tkwiłby zaczątek paradoksu: awangardyzująca forma wypowiedzi krytycznej stawałaby się antidotum na socrealizm. Krytyka socrealistyczna - przypomnijmy znaną tezę Janusza Sławińskiego - pozbawiała krytyka osobowości, nie miał on już wieku, płci, zainteresowań, żadnych cech stylu; był co najwyżej przekaźnikiem określonych partyjnych rozpoznań15. Błoński - w tym konkretnym tekście zdaje się przed tym skutecznie uciekać; w nieoczywisty sposób jednak - nie akcentuje w końcu własnej podmiotowości, chce stać się niby czystym patrzeniem, stara się samym sobą nie naruszać precyzji wywodu. Nic więc nie można mu zarzucić: w całości wydaje się on oddany opisowi swojego przedmiotu. Dla którego tworzy pewną przestrzeń ochronną: spokrewnienie - niezbyt daleko idące - Różewicza z nadrealistami (postępowymi i słusznymi ideologicznie) oraz odsunięcie go od awangardowej poetyki Przybosia dawało asumpt do bronienia tej twórczości także w zmieniającej się sytuacji politycznej.

\section{7.}

Tym bardziej zaskakuje więc przeskok: tej ostrożnej finezji nie ma już bowiem w sobie zupełnie kolejna wypowiedź Błońskiego o Różewiczu - opublikowana w piśmie „Wieś” w połowie 1950 roku $^{16}$. W przeciwieństwie do nieco od niej wcześniejszego omówienia „literackich obrachunków z latami okupacyjnymi", również wydrukowanego na tych samych łamach, analiza Różewicza

15 J. Sławiński Krytyka nowego typu, s. 137.

16 J. Błoński „Pogłosy i zapowiedzi”, „Wieś” 1950 nr 25, S. 5. 
nie jest przykładem wojującego socrealizmu; znika w niej jednak całkowicie subtelność krytyka, który nad analizę zdaje się teraz przekładać - etykietowanie. I tak: Niepokój to w twórczości Różewicza czas złowrogiego postkatastrofizmu, Czerwona rękawiczka to "pobyt w poetyckim sanatorium”, krytyk lepiej zaś od autora wie, że "miejsce w społeczeństwie zdobywa się za cenę kontaktu ze wszystkimi członkami tego społeczeństwa", i śledzi tego typu odruchy, jakie uwidaczniają się w Różewiczowskim dziele. Co więcej: zajmuje się on troskliwie buchalterią, wylicza, w ilu utworach z tomów wcześniejszych dostrzec moglibyśmy już zapowiedź słusznych ideologicznie rozrachunków, słowem - wyraźnie sytuuje się po stronie tych, którzy mają rację. Stwierdza wreszcie: „Przemiany poezji Różewicza odbywają się na osi «zaczadzenie» wojną - poszukiwanie nowego modelu człowieka”. Uwaga ta jest tak ogólna, że można ją także odnieść do samego komentatora - który szuka wówczas dla siebie miejsca - i języka. Czy Błoński dał się uwieść socrealistycznej poetyce? Odpowiedź, wbrew pozorom, nie jest łatwa. Niewątpliwie niekiedy z niej korzystał: powstawały wówczas teksty w oczywisty sposób toporne, w tej niezgrabności zaś wręcz przerysowane, nie bardziej jednak karykaturalne od innych licznych przejawów socrealizmu w szeroko rozumianych wypowiedziach okołoliterackich. Czy wolno się w nich dopatrywać tylko językowego pancerza, pozwalającego na przemycanie tych treści, które jeszcze dało się ukryć między wierszami? Niekiedy tak, choć nie zawsze: w wypadku niektórych z tych recenzji Błoński musiał zdawać sobie sprawę z tego, że jest niesprawiedliwy - bądź z tego przynajmniej, że uruchamia czytanie tylko i wyłącznie w kluczu ideologicznym. Casus twórczości Różewicza jest tu szczególnie znamienny: w końcu krytyk w dużej mierze podążał za ewolucją samego twórcy; zachęcał do niej, ponaglał, dotykał jednak tendencji, które już w niej kiełkowały ${ }^{17}$. Czy wolno w ogóle - czy ma to sens - obruszać się na krytyka,

17 Związki Różewicza z socrealizmem były wielokrotnie komentowane: zob. (w kolejności druku) A. Lam Różewicz - socrealista?, "Przegląd Humanistyczny” $1991 \mathrm{nr} 3 / 4 ;$ A. Ściepuro Wobec stalinizmu. Wiersze Tadeusza Różewicza z lat 1949-1956, „Pamiętnik Literacki” 1997 Z. 2; R. Cieślak Różewicz i socrealizm, w: Presja i ekspresja. Zjazd szczeciński i socrealizm, red. D. Dąbrowska, P. Michałowski, Wydawnictwo Naukowe US, Szczecin 2002; A. Kopkiewicz „Rozpadają się słowa / Którym odjęto miłość". Afekt, wspólnota i etyka "socrealistyczna" w powojennej poezji Tadeusza Różewicza, „Ruch Literacki” 2016 z. 2. Szczególnie interesujące wydają mi się ostatnie dwa teksty - Cieślak bardzo wyraźnie zwraca bowiem uwagę na te aspekty twórczości Różewicza, w których można odnaleźć wymiar polemiczny względem socrealizmu, Kopkiewicz socrealizm bierze w cudzysłów, używa go w znaczeniu metaforycznym, pytając raczej o to, jakie były u Różewicza powiązania między przywiązaniem do socjalizmu a kształtem projektowanej przez niego wspólnoty, do której mogła zbliżać bądź prowadzić literatura. 
że dokonywał wyborów bądź ocen literackich, które się nie potwierdziły z czasem? Błoński w dalszej części omawianego tekstu zdaje się odzyskiwać swobodę głosu: nic dziwnego, wraca bowiem do takiej poetyki recenzji, jaką przetestował przed rokiem: koncentruje się na aspektach formalnych. Odcinając coraz bardziej stanowczo Różewicza od polskiej awangardy, integruje go z nadrealistami, którzy ten nadrealizm z czasem porzucili. Ta operacja ideologiczna nie jest oczywiście neutralna - w ten sposób Błoński powoli starał się będzie stworzyć przeciwwagę dla takiej propozycji, jaką było przeszczepienie do polskiej literatury Majakowskiego. Zamiast tego poety podsuwać będzie - nie on jeden zresztą - Paula Éluarda; może to i nie ideał, lecz zawsze jakaś odsłona Zachodu. Socrealizm okazywałby się więc po raz kolejny maską; językiem, którego reguł trzeba się nauczyć, by nie stracić możliwości choćby niewielkiego oddziaływania na rzeczywistośćcis. Błoński nie jawi się tu jako buntownik - wybiera raczej strategię powolnego podkopywania tego

Takie odczytanie, jak sądzę, uwiarygodnia kontekst wypowiedzi Błońskiego, wnikliwie opisany przez Tadeusza Kłaka, który rekonstruował potyczki Różewicza z krytyką socrealistyczną (zob. tegoż Sceny z życia poety. Przygody Tadeusza Różewicza z krytyka socrealistyczna, w: Realizm socjalistyczny w Polsce z perspektywy 50 lat, red. S. Zabierowski, współpraca M. Krakowiak, Wydawnictwo UŚ, Katowice 2001). Wiele uwagi poświęcił on zwłaszcza artykułowi Andrzeja Brauna O poezji Tadeusza Różewicza („Nowa Kultura” 1951 nr 16), w którym krytyk szczegółowo dekonstruował dotychczasową twórczość poety, doszukując się w niej szeregu intertekstualnych nawiązań i kreśląc prognozy na przyszłość. Różewicz, widziany oczami Brauna, także był uczniem Eliota i Éluarda, następcą poetów przedwojennych ( $w$ tej wykładni podkreślano dziedzictwo skamadrytów) - inaczej jednak zupełnie niż u Błońskiego rozłożone zostały akcenty. Można wręcz powiedzieć, że zostały one odwrócone. To, co u Błońskiego było elementem zabezpieczania i wypracowywania nowego dyskursywnego pola, pozwalającego na opisanie specyfiki poezji Różewicza, u Brauna było już tylko oskarżeniem. Pokazuje to w moim odczuciu dwie rzeczy: (1) Błoński u progu lat 50. próbował się włączyć czynnie w życie literackie i zdawał sobie sprawę, że operacja taka będzie skuteczna tylko wtedy, gdy opanuje nowe reguły gry, (2) język socrealistycznej krytyki pozostał dla niego językiem obcym, do pewnego tylko stopnia wyuczonym - stąd pomyłki, potknięcia, wchodzenie w konflikty z socrealistyczną gramatyką. Słownik Błońskiego nie zgadzał się bowiem ze słownikiem innych komentatorów i to sprawiało, że od samego początku tkwił w nim - nie do końca chyba uświadamiany - potencjał subwersywny; potencjał, który uobecni się w pełni nie tylko w późniejszych wypowiedziach o Różewiczu (zwłaszcza tych przedrukowanych ostatecznie w zmienionym kształcie $w$ tomie Poeci i inni z 1956 roku), ale i w tych wszystkich wypowiedziach krytyka, które sprawią, że jeszcze przed Październikiem będzie on postrzegany jako enfant terrible młodej polskiej krytyki. Wystarczy przypomnieć, że utrzymany w bardzo kategorycznym tonie programowy artykuł Jerzego Putramenta Niektóre problemy naszej krytyki („Twórczość" 1955 nr 7) będzie odpowiedzią właśnie na jeden z tekstów Błońskiego. Trudno o mocniejsze wyeksponowanie nieprawomyślności niż w ujęciu Putramenta - Błoński, czytany w tym kluczu, uosabia bowiem wszelkie słabości krytyki burżuazyjnej, staje się prawie jej symbolem. 
monolitu, rozsadzania go od wewnątrz. Tu widzę początek strategii dla Błońskiego najbardziej może charakterystycznej: rozdwojenia na krytykę prywatną i publiczną; na treści prezentowane tylko w obiegu prywatnym oraz te, które mają z założenia dotrzeć do szerszej publiczności. Większość książek krytycznoliterackich Błońskiego byłam skłonna rozpatrywać w kategoriach krytyki zastępczej - funkcjonującej bowiem w rzeczywistości, w której nigdy nie wolno powiedzieć wszystkiego. W rzeczywistości, w której nawet o literaturze nie wolno mówić otwarcie, w której więc zafałszowane są z założenia hierarchie i kryteria ocen.

\section{8.}

Z socrealizmem w krytyce Błoński się rozliczy - ale jakby mimochodem, nie tyle komentując własne teksty ${ }^{19}$, co raczej działalność pokolenia swoich nauczycieli. W 1957 roku dwudziestosześcioletni krytyk opublikuje na łamach „Rocznika Literackiego” coroczne podsumowanie najważniejszych książek krytycznoliterackich ${ }^{20}$. Bardzo kategorycznie skomentuje tam Szkice literackie $i$ artystyczne $\mathrm{Wyki}^{21}$, zwracając uwagę na ich rozproszenie i eklektyzm, napisze: „liberalny, w miarę «formalistyczny» i w miarę «socjologiczny» Wyka zmienia się tam w Wykę-marksistę, całkiem już innego"22. Miało to zdaniem Błońskiego bardzo namacalne konsekwencje dla kształtu wypowiedzi (zarówno językowej, jak i myślowej):

Wyka eksperymentował metodologicznie w najtrudniejszym okresie, kiedy końcowe wnioski były właściwie znane z góry. W marksizmie lat pięćdziesiątych było mnóstwo myślowego automatyzmu: niejednego to zresztą uwodziło. Wyka chciał jednak pogodzić metodę z osobistymi doświadczeniami i zamiłowaniami. (A także - z obowiązkiem ratowania pewnych wartości literackich, zagrożonych przez literaturoburców...). Stąd nieoczekiwany skutek: niebywała czasem ekwilibrystyka interpretacyjna [...] łączyła się z przygnębiającą banalnością syntetycznych

19 W kluczu autorozrachunkowym można czytać dopiero fragmenty nieco późniejszej Zmiany warty [1961], której wstępne partie są rodzajem medytacji nad formami publicznego zaangażowania krytyka.

J. Błoński Krytyka literacka, „Rocznik Literacki” 1956 [wyd. 1957], s. 138-145. 
wniosków. Odbijało się to również na stylu krytyka - trudniejszym i bardziej zawikłanym. ${ }^{23}$

Nakładają się na siebie w tym komentarzu: zrozumienie okoliczności i rozczarowanie. Intelektualny kompromis - oglądany z perspektywy kilku lat - budzi ambiwalentne uczucia. Być może (pokazuje Błoński) nie dało się wówczas inaczej, przecież wysiłek Wyki oparty był na walce (z zastanymi formułami - stąd figura eksperymentu; walce o coś - stąd „obowiązek ratowania"), nie na mechanicznym przejmowaniu rozwiązań. Ale w ostatecznym rozrachunku gra nie była chyba do końca warta świeczki: „ekwilibrystyka interpretacyjna" może mieć wymiar dokumentu, nie stanie się jednak od razu - ważkim punktem odniesienia.

Równie krytycznie odniesie się Błoński do Moich odchyleń Sandauera ${ }^{24}$. Sądzić by można, że ta uparta walka o literacką nowoczesność będzie mu bliższa. Tak się jednak nie dzieje. Stwierdza on tylko sucho, że i ta książka jest dziś przede wszystkim świadectwem swego czasu, jej polemiczny wymiar wydaje mu się natomiast zupełnie martwy. Ten dystans nie jest tylko konsekwencją swoistej dezaktualizacji postulatów, głucho wybrzmiewających w odwilżowej rzeczywistości. Najważniejszym elementem omówienia Błońskiego pozostaje bowiem otwarte podkreślenie (pokoleniowej przede wszystkim?) różnicy: Sandauer miał być tym krytykiem, który z socrealizmem walczył z zewnątrz, nigdy go nie zaakceptowawszy, Błońskiego zaś o wiele bardziej zdaje się zajmować projektowany „pamiętnik krytyka, który doszedł do podobnych wniosków wychodząc od pierwotnej zgody na literaturę tzw. kultu jednostki". „Taki dziennik rozczarowanego adepta - dodaje - da nam prawdopodobnie Flaszen"25. Czy Błoński tę perspektywę bliskiego przyjaciela podzielał? Nie wiem. Ale wydaje mi się, że warto to pytanie o doświadczenie młodych krytyków w pierwszej połowie lat 50. poddać raz jeszcze pod dyskusję.

23 Tamże.

24 A. Sandauer Moje odchylenia, Wydawnictwo Literackie, Kraków 1956. Postawa Sandauera wobec socrealizmu została dogłębnie omówiona przez Grzegorza Wołowca - zob. tegoż Nowocześni w PRL. Przyboś i Sandauer, Wydawnictwo Leopoldinum, Wrocław 1999.

25 J. Błoński Krytyka literacka, s. 142. 


\section{Abstract}

\section{Małgorzata Szumna}

JAGIELLONIAN UNIVERSITY (CRACOW)

A Portrait of the Critic as a Young Man: Jan Błoński and the Formation of His Identity as a Critic

Drawing largely on unpublished archival material, Szumna outlines the most important tendencies in Jan Błoński's early criticism. She portrays the milieu from which Błoński emerged and shows how his interest in experimental literature influenced his literary criticism. Szumna also discusses the influences behind Błoński's earliest writings on Miłosz and Różewicz and the games he plays with the reader in these texts.

\section{Keywords}

Jan Błoński, Czesław Miłosz, Tadeusz Różewicz, literary criticism 